\title{
Anticardiolipin antibodies in ischaemic heart disease: marker or myth?
}

Kishor V Phadke, Rosalind A Phillips, David T R Clarke, Mary Jones, Patrick Naish, Peter Carson

\begin{abstract}
Objectives-To assess the incidence and significance of anticardiolipin antibodies after myocardial infarction and in unstable angina.

Design-A prospective study of all patients under 60 admitted to the coronary care unit over a 12 month period with a diagnosis of acute myocardial infarction who were followed up for a further 12 months. Patients admitted with unstable angina were similarly assessed but not followed up. Anticardiolipin antibody concentrations were compared with those of age matched controls.

Setting-A district general hospital.

Patients-307 patients with acute myocardial infarction and 160 patients with unstable angina.

Results-Anticardiolipin antibody concentrations in the two patient groups did not differ significantly from those in the control groups. Antibody concentrations were not related to a history of angina or myocardial infarction nor were they related to subsequent cardiovascular complications.

Conclusion-This study shows no significant association between anticardiolipin antibody concentrations and either myocardial infarction or unstable angina.
\end{abstract}

\section{(Br Heart f 1993;69:391-394)}

Departments of
Cardiology and
Immunology, North
Staffordshire Hospital
Centre, Stoke-on-
Trent, and
Departments of
Postgraduate
Medicine and
Mathematics, Keele
University,
Staffordshire
K V Phadke
R A Phillips
D T R Clarke
M Jones
P Naish
P Carson
Correspondence to:
Dr R A Phillips,
Department of Cardiology,
City General Hospital,
Newcastle, Stoke-on-Trent
ST4 6QG.
Accepted for publication
11 December 1992

An association between raised concentrations of anticardiolipin antibodies and recurrent arterial and venous thrombosis was first suggested in $1983 .{ }^{1}$ Subsequently two studies have reported an association between raised concentrations of antibodies and myocardial infarction. ${ }^{23}$ Also, an association was found between raised concentrations of anticardiolipin antibodies and failure of coronary artery bypass grafts. ${ }^{4}$ Other studies report an association between anticardiolipin antibodies and arterial and venous thrombosis in other sites, mostly in patients with autoimmune disorders. ${ }^{56}$

These antibodies are part of a family of antibodies to negatively charged phospholipids and are also related to the lupus anticoagulant. ${ }^{5}$ Phospholipids are important in the coagulation cascade as well as being components of endothelial cell walls and platelets.
It is an attractive concept that antibodies against phospholipids may be associated with ischaemic heart disease in patients without overt autoimmune disorders.

Hamsten et al reported a strong association between increased concentrations of anticardiolipin antibodies and subsequent cardiovascular events in young survivors of myocardial infarction but did not measure anticardiolipin antibody concentrations until three months after the acute event. ${ }^{2}$ Klemp et al reported a similar significant association between anticardiolipin antibodies on admission in myocardial infarction as well as angina pectoris but did not follow up their patients. ${ }^{3} \mathrm{~A}$ recent study by Sletnes et al did not show an association between anticardiolipin antibodies and myocardial infarction but measured antibodies only once, 28 days after the acute event. $^{7}$

The significance of anticardiolipin antibodies in patients with myocardial infarction and angina remains uncertain. Furthermore, some workers did not measure antibodies immediately after the acute events and it is not clear if these antibodies precede infarction or develop subsequently. This study was therefore planned to clarify the significance of anticardiolipin antibodies in ischaemic heart disease.

\section{Patients and methods}

During a 12 month period from June 1988, all patients under the age of 60 admitted to the coronary care unit with acute myocardial infarction or unstable angina were studied. Major risk factors for ischaemic heart disease (age, sex, previous myocardial infarction or angina, smoking, hypertension, diabetes, and serum cholesterol) were recorded.

Three hundred and seven patients (245 men and 62 women) with acute myocardial infarction were admitted. The diagnosis was confirmed by electrocardiographic changes and/or increased cardiac enzymes. Eight patients died before anticardiolipin antibodies could be measured and were excluded. The remaining 299 patients formed this study group. The median age was 53 years (men 52, women 54.5). Anticardiolipin antibodies were measured on day 1 and day 5 . Routine investigations on day 1 included full blood count, erythrocyte sedimentation rate, cholesterol concentration, and an autoimmune screen consisting of antinuclear factor, antimitochondrial antibodies (antibodies to M2 
and M5), ${ }^{8}$ and antismooth muscle antibody. Cardiac enzymes were measured on days 1 , 2 , and 3. All surviving patients were reviewed in the cardiac out patient clinic at five weeks, five months, and 12 months after myocardial infarction with a full history, clinical examination, electrocardiogram, and anticardiolipin antibody estimations.

Five patients who lived outside the district were not followed up and two patients dropped out from follow up. Standard treatment included streptokinase, intravenous heparin for the first 24 hours, and 150 to 300 $\mathrm{mg}$ of aspirin daily where appropriate.

The unstable angina group consisted of 99 men and 61 women (160), median age 52 (men 51, women 52). The diagnosis was based on a history of prolonged cardiac pain without electrocardiographic or enzyme changes associated with infarction. Anticardiolipin antibodies were estimated on day 1 with the same routine investigations and autoimmune screen. Standard treatment included 150 to $300 \mathrm{mg}$ of aspirin daily. The angina patients were not followed up for the purpose of this study.

Serum samples from age and sex matched controls were taken from a group of 504 normal people (blood donors or patients attending the pathology department for a routine biochemical screening with no history of ischaemic heart disease).

\section{DETECTION AND ASSAY OF ANTICARDIOLIPIN \\ ANTIBODIES}

Anticardiolipin antibodies were measured by an enzyme linked immunosorbent assay (ELISA) standardised against the Rayne Institute control material. ${ }^{10}$ Serum samples were screened at a dilution of 1:50 with alkaline phosphatase conjugated to antibodies to IgG, IgA, and IgM (Sigma, Poole, UK) at dilutions of 1:400. Positive results were recorded as five SDs above the mean of pooled normal human serum. ${ }^{1011}$ Positive results were confirmed and measured for IgG and IgM anticardiolipin antibodies with specific isotype antisera and a commercial immunoassay (Cambridge Life Sciences, Ely, UK). ${ }^{11}$ Values for anticardiolipin antibodies (IgG phospholipid units/ml (GPL) and IgM phospholipid units/ml (MPL)) were classified as normal, low, medium, and high (table 1 ).

\section{STATISTICAL METHODS}

The associations between anticardiolipin antibodies and risk factors, and anticardiolipin antibodies and subsequent adverse cardiovascular events were analysed by $\chi^{2}$ or Fisher's

Table 1 Classification of anticardiolipin antibody concentrations phospholipid units/ml (GPL and MPL)

\begin{tabular}{lll}
\hline & $\operatorname{IgG}(G P L)$ & $\operatorname{IgM}(M P L)$ \\
\hline Normal & $<5$ & $<3$ \\
Low & $5-14 \cdot 9$ & $3-5 \cdot 9$ \\
Medium & $15-100$ & $6-60$ \\
High & $>100$ & $>60$ \\
\hline
\end{tabular}

IgG, immunoglobulin $G$ anticardiolipin antibody; IgM, immunoglobulin $\mathbf{M}$ anticardiolipin antibody. exact test. A comparison of the percentage of patients with raised antibodies at different times was analysed by McNemar's test. As multiple tests increase the possibility of false positive results, a significance level of 0.005 was used for these paired comparisons.

Approval for the study was obtained from the North Staffordshire Hospital Centre ethics committee. Informed consent was obtained.

\section{Results}

MYOCARDIAL INFARCTION

Anticardiolipin antibodies

Anticardiolipin antibody concentrations on admission were not significantly increased in patients with myocardial infarction compared with controls (table 2). Subdivision of results into low and medium positive anticardiolipin antibodies in patients and controls gives numbers too small for analysis. Only two patients had a high positive IgM (one on admission and one at 12 months) and no patient had a high IgG at any time.

There was no significant association between the presence of anticardiolipin antibodies and major cardiovascular risk factors including previous myocardial infarction or angina.

During follow up there was an apparent increase in the percentage of patients with raised IgG (with a peak at five months) but this did not reach significance. The percentage of patients with raised IgM did not change over the 12 month follow up period.

\section{Other autoantibodies}

There was no significant association between the presence of antinuclear factor, antismooth muscle, antibodies to M2 or M5 and anticardiolipin antibody concentrations at any time. The only patient with systemic lupus erythematosus had an antinuclear factor of $1: 160$ on admission, and an IgG of $23 \mathrm{GPL}$ units and IgM of $13 \mathrm{MPL}$ units at five weeks.

\section{Complications}

In the seven patients who died in hospital and the 12 who died during follow up there was no significant association with anticardiolipin antibody concentrations. Similarly, there was no association with further myocardial infarction: nine patients had a second myocardial infarction in hospital and 19 had a further myocardial infarction during follow up.

Analysis of patients' highest IgG (at any time) subdivided into low and medium positive, failed to show a difference between the patients who did and did not have adverse

Table 2 Details of raised anticardiolipin antibodies (ACA) on admission in patients with myocardial infarction (MI) compared with controls

\begin{tabular}{llll}
\hline$A C A$ & $M I$ patients & Controls & Odds ratio (95\% CI) \\
\hline IgG & $6.8 \%$ & $4.2 \%$ & $1.68(0.78$ to 3.64$)$ \\
$\geqslant 5$ GPL & $5.0 \%$ & $5.0 \%$ & $1.0(0.45$ to $2 \cdot 2)$ \\
IgM & & & \\
$\geqslant 3$ MPL & & &
\end{tabular}

Abbreviations as for table 1.

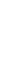

(1)


Table 3 Details of raised anticardiolipin antibodies $(A C A)$ on admission in patients with angina compared with controls

\begin{tabular}{llll}
\hline$A C A$ & Angina patients & Controls & Odds ratio (95\% CI) \\
\hline IgG & $6.3 \%$ & $2.5 \%$ & $2.6(0.8$ to 8.47$)$ \\
$\geqslant 5 \mathrm{GPL}$ & $4.4 \%$ & $4.4 \%$ & $1.0(0.34$ to 2.92$)$ \\
IgM & & & \\
\hline
\end{tabular}

Abbreviations as for table 1.

events within the two groups $(p=0.51)$. A similar analysis of patients' highest IgM was not possible due to small numbers.

Of the four patients who developed pulmonary embolism one had a medium positive Igm at five months. One of the three patients who developed deep vein thrombosis had a low positive IgM on admission. The only patient to develop systemic embolism (femoral) had no anticardiolipin antibodies at any time. These numbers are too small for analysis. Sixteen patients developed pericarditis in hospital but there was no significant association between the presence of pericarditis and anticardiolipin antibody concentrations at any time.

No patient developed Dressler's syndrome.

\section{Treatment}

One third of the patients received thrombolytic drugs and intravenous heparin. Four percent of patients were already taking aspirin before admission and a further $86 \%$ started aspirin from the first day in hospital. At the 12 month follow up visit $79 \%$ were taking aspirin. There was no significant association between anticardiolipin antibody concentrations and treatment with aspirin.

\section{Younger patients}

A separate analysis of patients under 50 years of age did not differ from that of the total group.

ANGINA

\section{Anticardiolipin antibodies}

Anticardiolipin antibody concentrations on admission were not significantly higher in patients with angina than in controls (table 3). Subdivision of the anticardiolipin antibody results into low or medium positive groups gave numbers too small for analysis. No patient had high IgG or IgM. As in the myocardial infarction group, there was no significant association between the presence of anticardiolipin antibodies and major cardiovascular risk factors including a history of myocardial infarction or angina.

\section{Other autoantibodies}

There was no significant association between the presence of antinuclear factor, antismooth muscle, antibodies to M2 or M5 with anticardiolipin antibody concentrations in angina patients.

\section{Treatment}

On admission $13 \%$ were already taking aspirin and a further $60 \%$ were started on aspirin on the first day in hospital. There was no significant association between anticardiolipin antibody concentrations and treatment with aspirin.

\section{Discussion}

In this study the incidence of anticardiolipin antibody on admission in a consecutive group of patients with myocardial infarction was low and not significantly different from a control group. There was a non-significant rise in IgG antibody at five months but the presence of, or a change in, antibody concentrations did not predict further cardiovascular complications. Similarly in a group of patients admitted with unstable angina, anticardiolipin antibody concentrations were not significantly different from a control group. The presence of these antibodies was not associated with a history of myocardial infarction or angina in either group.

Our results are, therefore, broadly in agreement with those of Sletnes et $\mathrm{al}^{7}$ but contrast considerably with the results of Hamsten et al who selected young survivors of myocardial infarction ${ }^{2}$ and Klemp et al who did not follow up their patients. ${ }^{3}$ Although these two positive studies used similar assay methods to ours, they did not use the now generally accepted international reference preparation ${ }^{10}$ and chose as a positive result, two to four SD of the mean of a control group. It is probable that a proportion of their positive results would now be considered negative but this is unlikely to explain fully the difference between their results and ours. Ninety per cent of our patients received aspirin from the first day of admission. Neither Hamsten et al nor Klemp et al record if their patients did so. ${ }^{23}$ It is possible that aspirin reduces tissue damage by the inhibition of thromboxane A2 production and consequent platelet aggregation. As patients in the study of Sletnes $e t a l^{7}$ did not receive aspirin, this hypothesis is also an unlikely explanation for our negative results.

Unlike the study of Hamsten et $a l^{2}$ both our study and that of Sletnes et al do not show an association between the presence of anticardiolipin antibodies and subsequent cardiovascular complications. Similarly there was no association between these antibodies and cardiovascular complications in the younger patients in our study.

In conclusion our results strongly suggest that there is no association between anticardiolipin antibodies and ischaemic heart disease. This study was supported by grants from the North Staffordshire Heart Committee and the trust funds of
diac department, North Staffordshire Hospital Centre.

We thank Dr M Clarke and Dr J Davis for permission to include their patients and Dr Ala, Director of the Birmingham Blood Transfusion Service for permission to use blood donor samples. We also thank Dr R Ibbotson and Dr R Neary for their help and advice and Mrs Sue Birchall for her secretarial assistance.

1 Harris EN, Gharavi AE, Boey ML, Patel BM, Mackworth-Young C G, Loizou S, et al. Anticardiolipin 
antibodies: detection by radio-immunoassay and association with thrombosis in systemic lupus erythematosus. Lancet 1983;ii:1211-4.

2 Hamsten A, Bjorkholm M, Norberg R, deFaire U, Holm G. Antibodies to cardiolipin in young survivors of myocardial infarction: an association with recurrent myocardial infarction: an association with

3 Klemp P, Cooper RC, Strauss FJ, Jordaan ER Przybojewski J, Nel N. Anticardiolipin antibodies in ischaemic heart disease. Clin Exp Immunol 1988;74: 254-7.

4 Morton KE, Krilis SA, Baron DW, Gavaghan TP, Daggard GE, Hickie JB, et al. Coronary artery by-pass graft failure-an autoimmune phenomenon. Lancet 1986;ii:1353-7.

5 Harris EN, Asherson RA, Hughes GRV. Antiphospholipid antibodies-autoantibodies with a difference. Ann Rev Med 1988;39:261-71.

6 Asherson RA, Mackay IR, Harris EN. Myocardial infarction in a young man with systemic lupus erythematosus, deep vein thrombosis, and antibodies to phospholipid.
Br Heart f 1986;56:190-3.

7 Sletnes KE, Smith P, Abdelnoor M, Arnesen H, Wisloff F. Antiphospholipid antibodies after myocardial infarction and their relation to mortality, reinfarction and non-haemorrhagic stroke. Lancet 1992;339:451-6.

8 Meroni PL, Harris EN, Brucato A, Tincani A, Barcellin W, Vismara A, et al. Anti-mitochondrial type M5 and anticardiolipin antibodies in autoimmune disorders: studies on their association and cross-reactivity. Clin Exp Immunol 1987;67:484-91.

Loizou S, McCrea JD, Rudge AC, Reynolds R, Boyle CC, Harris EN. Measurement of anticardiolipin antibodies by an enzyme-linked immunosorbent assay (ELISA) standardization and quantification of results. Clin

10 Harris EN, Gharavi AE, Patel SP, Hughes GRV Evaluation of the anticardiolipin antibody test: report of an international workshop held 4 April 1986. Clin Exos Immunol 1987;68:215-22.

11 Harris EN, Hughes GRV. Standardisation of the anticardiolipin antibody test [letter]. Lancet 1987;i:277. 